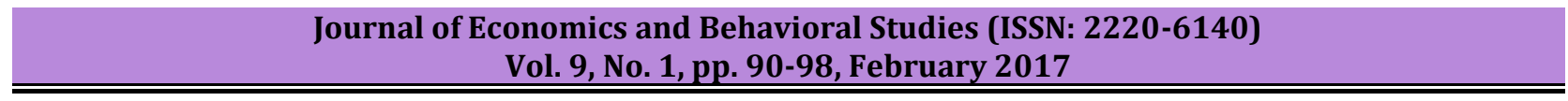

\title{
Nexus of Working Capital Management and Firm Performance in Nigerian Food and Beverages Industries: A Link with Risk-Return Theory
}

\author{
Odunayo Magret Olarewajuํㅜ, Mishelle Doorasamy ${ }^{1}$, Titilayo Moromoke Oladejo ${ }^{2}$ \\ 1University of KwaZulu-Natal, Westville Campus, Durban, South Africa \\ ${ }^{2}$ Obafemi Awolowo University, Ile-Ife, Nigeria \\ olarewaju_odunayo@yahoo.com, doorasamym@ukzn.ac.za, oladejotitilayo2011@gmail.com
}

\begin{abstract}
This paper examines the nexus of working capital management and financial performance of selected multinational food and beverages industries in Nigeria for the period between 2006 and 2014 and establishes its linkage with risk-return theory. An explanatory research design is adopted and the secondary data used were gathered from 5 purposively selected quoted food and beverages companies using GLS panel regression analysis. The pooled regression shows that account receivable ratio (ARR) and debt ratio (DER) have negative effect but significant at $1 \%$, working capital (WCA) is also significant at $5 \%$ but had positive effect, however, sales growth (SGR) was insignificant. It is also discovered from the Fixed Effect Estimation that working capital management variables such as account receivable ratio (ARR) and debt ratio (DER) have negative effect but significant at 1\%, working capital (WCA) is also significant at $5 \%$ but has positive effect, while sales growth (SGR) has negative effect but insignificant to the performance of the companies. This signifies reduction in the performances of food and beverages industries which calls for urgent attention since they are posting inverse effect. The unison in both estimations shows that those variables are the major factors influencing the performance of food and beverages industries in Nigeria and thus, it is concluded that the management board of these industries should restructure their working capital management policy as it has the tendency of affecting the dividend policy and firms' liquidity, which invariably affects the maximization of shareholders' wealth. This can only be done when managers reduce account receivable days; ensure proper debt management technique, improve sales strategies to enhance sales growth as well as maintain optimal working capital level to reflect the risk-return theory of firms.
\end{abstract}

Keywords: Debt Ratio, Account receivables, optimal working capital, Risk-Return theory, Generalized Least Square

\section{Introduction}

Over the years, working capital management has been a strategic management decision on the structuring and maintaining of short term assets and liabilities in such a way that will generate an efficient level of these inputs and ensure availability of adequate cash flow that can meet the firms' short term obligation (Kaur, 2010). The success of any firm depends solely on the financial managers' ability to effectively manage its working capital components. Working capital management is one of the trilogies (capital budgeting and capital structure being the other two) of corporate financial management that has great effect on financial goals in a firm (Wanguu, 2015). Working capital is also a vital issue to be considered in making any financial decision, be it dividend, investing and funding because it has a direct influence on firms' liquidity and performance because it is a constitutional part of the investment, unfortunately, it is always underrated when making financial decisions in the corporate world (Ray, 2012). Most firms view it as something meaningless in firms' decisions because it does not have any contribution to firms' return on equity (Sanger, 2001). According to Eljelly (2004), effective management of working capital requires a balancing wheel between reduction of illiquidity and avoidance of excess asset composition. An optimal working capital in a firm will maximize revenue by increasing the firms' free cash flow (Ganesan, 2007). It is evident that firms often increase their cash level instead of just holding a fraction of their assets. European Monetary Union corporations hold 15\% of their total assets as cash or cash equivalents while U.S. industrial firms hold an increasing rate of $129 \%$ as their average cash to total asset trend ratio (Ferreira \& Vilela, 2004). Mathematically, working capital is the difference between current assets and current liabilities and the major components of working capital are cash and cash equivalents accounts receivable, inventories and accounts payable which no firm can do without. Because working capital can be substituted for cash and changes in working capital affect the viability of the firm, there is the need to constantly review its structure and management and its effects on performance. With the current economic recession in Nigeria and increasing inflation rate, most business organizations are collapsing simply because 
their working capital is not well managed to be able to absorb losses and stand firm in the turbulent periods. A firm's value can only be maximized if the firm maintains an optimal level of its working capital (Deloof, 2003).

Therefore, firms should note that the main objective of working capital management is to maintain a trade off among its components and ensure that optimal level of working capital is constantly maintained to face any future challenges (Filbeck and Krueger, 2005). Nigerian firms would have escaped financial difficulty and bankruptcy if there has been an effective and efficient working capital because adequate management of working capital brings financial flexibility. Based on the foregoing, this research paper will not only re-examine if there is any relationship between working capital management and financial performance but also establish its linkage with risk-return theory using selected working capital variables in Nigerian context in that they (firms' financial managers) must maintain a balance between maintaining adequate working capital and achieving greater financial performance in order to enhance sustainability of the firms. One objective should not be detrimental to the achievement of the other because both play important roles in ensuring the firm's performance. For a longer time survival, adequate care and consideration must be given to the profit margin. However, to avoid the problem of insolvency or bankruptcy, the state of liquidity must not be neglected, rather, a proper and adequate attention must be paid to it. On this note, this paper will analyze the relationship among Working Capital, Account Receivable Rate, Debt Ratio, Sales Growth and Returns on Asset which is the chosen measure of financial performance of firms. For easy flow of ideas and logical presentation, this paper is structured into 5 sub-sections. The next section reviews the relevant literatures. Section three covers the research design, research method and model specification. Section four focuses on the analysis, interpretation and relevant discussion of the analysis output, and section five concludes the paper.

\section{Literature Review}

Major Determinants of Firms' Working Capital: Working capital plays a crucial role in the survival of a firm but it is not an end in itself, rather, a means of getting to an end (Chand, 2016). A rational company will always want to hold working capital, no matter how small it may be due to its tendency to minimizing solvency risk. The following are the key factors that determine the working capital of a rational firm; a) Company's dividend policy; there is always a balance between working capital and dividend policy of a firm because no firm will stick to a particular dividend policy either payout or re-investment plans without considerations for the availability and future need of cash. A high liquid firm will want to choose payout rather than re-investment and vice versa. b) Circulating capital turnover; the rate at which cash can be easily converted to raw material and raw materials to finished goods is a key predictor of setting an adequate working capital for firms. c) The nature of business; working capital set-up differs for firms according to the nature of business they carry out. If it is a trading firm, it requires huge liquid capital and if it is a manufacturing company, its requirement for working capital depends on what it produces, hence, a firm's working capital depends on what the company sets to carry out. d) Economic instability and inflation; working capital level of firms depend on the stability of the business cycle and the economy they find themselves. A rational firm will always want to take the advantage of buying stocks at lower prices and selling it at a higher price to generate profit, but if they have higher stock and price declines, it affects their working capital and later results into loss and vice versa. e) Frequency of production; a firm that produces frequently will often set working capital to meet each production schedules since each production plan has a required level of liquid capital to consume. f) Operational expenses; the higher the operating cost of a firm, the higher the level of cash required. Working capital is needed to pay staff salaries, office rents, electricity rates, advertising costs etc. As the requirement of cash goes up in the company, the more the company needs working capital. Lastly, unforeseen circumstance and hazard determine the level of working capital in a firm.

Link between Working Capital Management and Profitability Using Risk-Return Theory: This theory shows the relationship between risk and return in a portfolio and it has been reviewed by various researchers in diverse sectors of the economy since every decision on investment is a gauge of the relationship between risk and return derived from the risk (Mukherji, Desai \& Wright, 2008). Most investors in organisations are mostly risk averse but their managers are risk seekers who will always take decisions with greater loss probability and with the aim of a higher futuristic gain. However, the link between working capital management and risk-return theory is that one of the main decisions on working capital is the trade-off between liquidity and profitability. A higher liquidity level is always at the expense of profitability and vice 
versa. Making these two decisions either increases or decreases the components of working capital in an organization. In terms of cash, when it is in excess, it indicates idleness and low earnings, while when there is its shortage; it causes liquidity crisis and disruptions in firms' operations. In terms of firms' receivables, it indicates probability of default and retrieval cost, while at shortage level, it depicts probability of a low profitability. Also, excess inventory indicates the probability of opportunity and carrying cost of funds which is a signal of low profit, while shortage inventory level tends to lower profit in terms of limited supplies, production interruption and lower sale which will invariably lower their profitability. Moreover, risk-return theory is related to working capital in terms of the inward looking at financial managers' ability to determine their collection of asset since they must relate with their environments as it is impossible for them to own everything they need to carry on the business. Decisions of the mixture of inventory, receivables, stocks and profitability are all under the risk-return postulations (Muneer, 2015; Aminu \& Zainudin, 2015).

Figure 1: A Diagrammatic Representation of Working Capital Management and Performance as a RiskReturn Relationship.

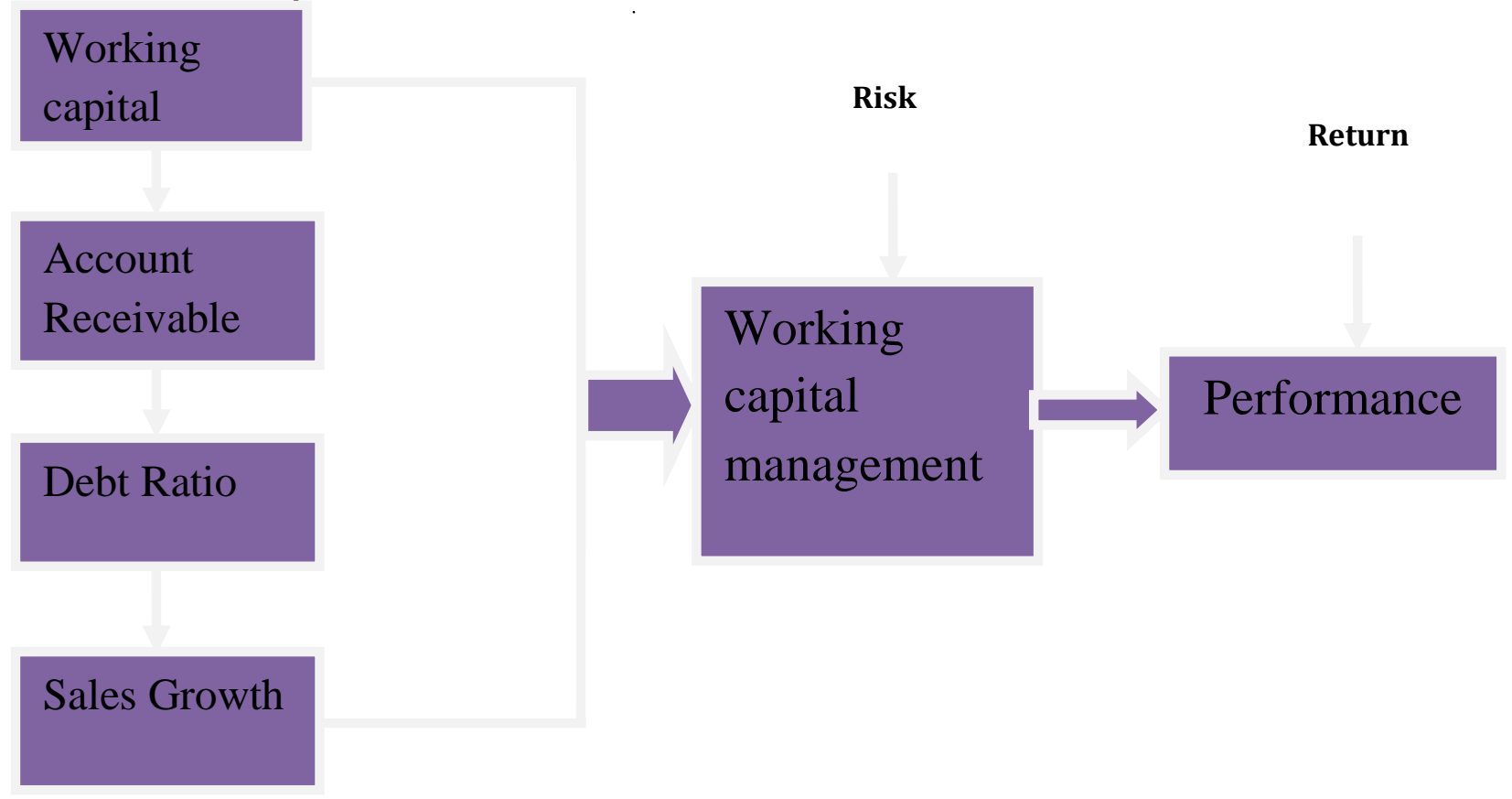

Source: Author's Design 2016

Empirical Literatures: There are numerous literatures on working capital management in diverse sectors of the economy due to its key role towards the realization of optimal working capital that is capable of maintaining equality between firms' liquidity and profitability. However, findings from the various studies show that there are mixed and inconclusive results on the nexus of working capital management and performance by the level of disparity in the significant variables. This calls for further empirical researches on the subject matter such as the current study. Deloof (2003), in his study of working capital management in Belgium, found a highly significant relationship among the examined working capital measures and profitability of corporate firms. It was concluded that a firm with an increasing profitability must have its account receivable and inventories days reduced. The findings, therefore, support the proposition of Wang (2002) that reduction in inventories and account receivable days will lead to an increased level of profitability. Conversely, in the study carried out by Lyroudi and Lazaridis (2000) in investigating the relationship among cash conversion cycle, size, firms' profitability, and firms' debt level found a significant and direct relationship among the current ratios of firms, ROA, net profit margin and their cash conversion cycle, but inversely related to their debt to equity ratio, They concluded that the liquidity ratios of both large and small firms are relatively the same. Filbeck and Krueger (2005) examined US listed firms and firms listed on Athens Stock Exchange using a sample of 131 companies covering 2001 to 2004, and they found that there is a significant direct relationship between gross operating profit and cash conversion cycle of the firms examined. They concluded 
that firms tend to maximize shareholders' value by proper handling of their cash conversion cycle to be at an optimum level. In the study of Karachi listed companies, Raheman and Nasr (2007) examined 94 firms between 1999-2004 and found that working capital management variables have strong inverse relationship with corporate profitability while sales growth that was used to proxy size had positive relationship with profitability. Contrarily, Sharma and Kumar (2011) found in Indian companies that a number of inventory days and account payable days are inversely correlated with their profitability, whereas the accounts receivable days and cash conversion days are positively correlated to profitability. An empirical study by Yeboah and Agyei (2012) on Ghanaian banks from 1999-2008 using panel data technique found that debtors' collection period had positive relationship with profitability while creditors' payment period had significant negative relationship with profitability. The study added that effective management of credit and exchange risk of banks significantly increases their profitability. They conclude the study by recommending improvement on cash conversion cycle to banks since the interest income generated by banks is a function of the availability of credit for lending.

In the same vein, several empirical studies have also been conducted in Nigerian context and their findings have also been mixed and inconclusive. For instance, in a study conducted by Falope and Ajilore, (2009), firms' profitability is reduced by increasing the length of account receivable days, inventory days and accounts payable days. Specifically, they conclude the study by declaring that a shorter cash conversion cycle improves Nigerian firms' profitability. Also, Akinlo (2012) investigated the working capital determinants of 66 selected firms in Nigeria using panel data approach from 1997-2007. The study reveals that economic activities, growth in sales, operating cycle, size and a stable working capital are firm-specific factors that positively influence working capital policy in a firm. Leverage, however, was found to be inversely related to working capital requirements and the study concludes that sales growth, inventory period, cash conversion cycle, and account receivable days affect firms positively, while account payable period and leverage affect firms' profitability inversely. Owolabi and Alu (2012) conversely found that all the working capital management variables are insignificant to spur profitability in Nigerian Manufacturing firms. On the other hand, Uremadu et al. (2012) examine both working capital management and liquidity effect on profitability of listed firms in the Nigerian productive sector just for 2005-2006 using ordinary least square (OLS) method. They discover a negative relationship among cash conversion cycle, creditors' payment period and profitability and a positive relationship among inventory conversion period, debtors collection days and profitability. It is also discovered that cash conversion cycle remains the most significant precision variable which predicts corporate profitability in Nigeria.

Also, Imeokparia (2015) found a positive relationship among management efficiency level, improved accurate cost, profit information and working capital. He also found out that working capital management is positively related to the profitability of food and beverages industries. He concludes that working capital management affects organizations' performance in terms of their liquidity and efficiency and does not determine their profitability. A critical examination of various research works and literatures reveal that several studies had been carried out on the subject matter in both developed and developing economy, Nigeria inclusive. These researchers have used different approaches and methodologies ranging from descriptive, explanatory survey and regression techniques to investigate the subject matter, however, their various findings and conclusions have been largely inconclusive. This paper wishes to contribute to knowledge and fill the gap in the existing literature on working capital management and financial performances in terms of the newly adopted technique of analysis in Nigerian context. To this end, the work will make use of generalized least square fixed panel model to examine five purposively selected multinational food and beverages industries with branches in Nigeria.

\section{Methodology}

This descriptive and correlation research work falls under the positivist paradigm being a pure quantitative research. The paper tends to obtain consistent estimate of GLS Pooled and fixed effect models for panel data regression applied to data from five (5) multinational food and beverages industries in Nigeria between 2006 and 2014 based on the available information on the financial variables or working capital management components considered for this paper. These companies are Flour Mills Nigeria Plc, Cadbury Nigeria Plc, Nestle Plc, Nigerian Bottling Company Plc and 7-Up Nigeria Plc. The secondary data used were obtained from the 
annual reports and accounts of these selected companies. These 5 purposively selected companies serve as cross-section units and the years involved as time periods.

\section{Specification of Model}

Panel GLS Models: In general, linear models for panel data, the intercept and slope coefficients vary over both cross-sections and time:

$$
\begin{aligned}
& Y_{i t}=a_{t i}+\beta_{i t} X_{i t}^{\prime}+u_{i t} \ldots \ldots . . \\
& i=1 \ldots \ldots, N, t=1 \ldots \ldots \ldots ., T .
\end{aligned}
$$

Where $Y_{i t}$ is a scalar regress and, $X_{i t}$ is a $k \times 1$ vector of the regressors, $u_{i t}$ is a scalar stochastic white noise error term, $i$ indexes individual companies and $t$ indexes the time period. The model $(i)$ is too general and not estimable as there are more parameters to be included in the estimation. Hence, there is a further restrictions on the extent to which the intercept $a_{i t}$ and coefficient $\beta_{i t}$ vary with $i$ across $t$, and over the behavior of $u_{i t}$.

GLS Fixed Effects Model: The GLS fixed effects model specify that:

$$
\begin{aligned}
& Y_{i t}=a_{i}+\beta_{i} X_{i t}^{\prime}+u_{i t} \ldots \ldots \ldots \ldots \\
& i=1, \ldots \ldots \ldots, N, t=1, \ldots \ldots \ldots, T
\end{aligned}
$$

Note that the individual-specific effects $a_{1}, a_{2}, \ldots \ldots \ldots \ldots \ldots \ldots \ldots a_{N}$ measure the unobserved heterogeneity that might be correlated with the explanatory variable $X_{i t} . \beta_{i}$ are $k \mathrm{x} 1$ vectors of estimated coefficient, and the errors term $u_{i t}$ are $\ddot{i i d} \approx N\left(0, \sigma^{2}\right)$.

Increase in $\mathrm{N}$ individual-specific effects pose a major challenge for estimation as the $\mathrm{N}$ tends to become large. This paper is only interested in the slope parameter $\beta_{i}$. The $\mathrm{N}$ parameters $a_{1}, a_{2} \ldots \ldots \ldots \ldots . . . a_{N}$ are incidental parameters that have no intrinsic interest and value in this paper.

The GLS fixed effect model used for this analysis is thus expressed as:

$$
Y_{i t}=a_{i}+\beta_{i} X_{i t}^{\prime}+u_{i t}
$$$$
i=1, \ldots \ldots . . .5, j=1, \ldots \ldots . ., 4, t=1, \ldots \ldots \ldots, 9
$$

Equation ( iii ) above is expressed as:

$$
Y_{i t}=a_{i}+\beta_{i} X_{i t}^{\prime}+u_{i t} \ldots \ldots \ldots \ldots \ldots \ldots \ldots \ldots \ldots \ldots . .(i v)
$$

In order to avoid the problem of outliers, there is need for linear transformation of the variables. That is:

$$
\log Y_{i t}=a_{i}+\beta_{i} \log X_{i j t}+u_{i t}
$$

Let $\log Y_{i t}=Y_{i t}^{*}$ and $\log X_{i j t}=X_{i j t}^{*}$

Now the equation ( $\mathrm{v}$ ) becomes:

$Y_{i t}^{*}=a_{i}+\beta_{i} X_{i j t}^{*}+u_{i}$

$i=1, \ldots .5, t=1, \ldots \ldots . .9, \beta_{i}=\beta_{1}-\beta_{4}$ where $a_{1}=a_{2}=a_{3}=0$

Where;

$X_{i j k}$ is a $k \times \mathrm{j}$ vector of regressors and $\beta_{i}=\left(\beta_{1}-\beta_{4}\right)$

$X_{i t}^{\prime}=(W C A, A R R, D E R, S G R)_{i t}$

Explicitly,

$$
R O A_{i t}=a_{i}+\beta_{1} W C A_{i t}+\beta_{2} A R R_{i t}+\beta_{3} D E R_{i t}+\beta_{4} S G R_{i t}+u_{i t}
$$

Therefore,

$$
Y_{i t}=R O A, X_{1}=W C A, X_{2}=A R R, X_{3}=D E R, X_{4}=S G R
$$


$u_{i t}$ is the white noise error term showing the percentage of unexplainable ROA by the WCA, ARR, DER and SGR.

Variables Description: The variables used in this research are selected multinational food and beverages company performance captured by the return on assets (ROA) and the proxies of working capital management are working capital (WCA), account receivable (ARR), debt ratio (DER) and sales growth (SGR). These variables are used as components of working capital management that influence or determine the performance of the industries under investigation.

\begin{tabular}{|c|c|c|}
\hline VARIABLES & DESCRIPTION & EXPECTATION \\
\hline ROA & $\frac{\text { Pr } \text { ofitaftert ax }_{i t}}{\text { TotalAsset }_{i t}} * 100$ & \\
\hline WCA & $\frac{\text { Currentasset }}{\text { Currentliabilities }} * 100$ & Positive \\
\hline ARR & $\frac{\text { Accountrec eivables }}{\text { Totalcreditsales }} * 365$ days & Positive/Negative \\
\hline DER & $\frac{\text { TotalLiabilities }_{i t}}{\text { TotalAssets }_{i t}} * 100$ & Negative \\
\hline SGR & $\frac{\text { Sales }_{i t}-\text { Sales }_{i(t-1)}}{\text { Sales }_{i(t-1)}} * 100$ & Positive \\
\hline
\end{tabular}

\section{Analysis and Discussion of Results}

This section deals with the analysis of descriptive analysis, panel GLS regression (common and fixed or cross sectional effect) model of WCM and the performance of the selected Nigerian multinational food and beverages industries.

Table 1: Pooled Generalized Least Square Panel Regression Result

\begin{tabular}{lllll}
\hline Variables & Coefficients & S. Error & t-Stat & Prob. \\
\hline C & 0.125630 & 0.011086 & 11.33276 & 0.0000 \\
ARR? & -0.113399 & 0.024795 & -4.573529 & 0.0000 \\
DER? & -0.123099 & 0.023464 & -5.246332 & 0.0000 \\
SGR? & $-1.21 \mathrm{E}-07$ & $1.29 \mathrm{E}-06$ & -0.093794 & 0.9256 \\
WCA? & $1.37 \mathrm{E}-09$ & $5.80 \mathrm{E}-10$ & 2.360288 & 0.0218 \\
\hline
\end{tabular}

R-Squared $=0.45$ Adj. R-Squared $=0.41$ F-Stat. $=11.354$ Prob. $($ F-Stat. $)=0.000$

Source: Researcher's Computation 2016

Table 1 shows the result of the pooled generalized least square panel regression output. It is discovered from the result that the relationship between working capital management and the performance of food and beverages industries in Nigeria is linear. It is found that there is an inverse linear relationship between the following pairs of variable: account receivable rate and return on assets; debt ratio and the return on assets and sales growth and the return on assets of the industry while working capital and the return on assets of the industry show a positive linear relationship. This is contrary to Akinlo (2012) who found out that account receivable ratio, sales growth, cash conversion cycle and inventory period have positive effects on firms in Nigeria. The result further reveals that the account receivable rate, debt ratio and sales growth reduce the performance of food and beverages industries measured by return on assets by $11.3,12.3$ and $1.21^{*} 10^{-7}$ percent respectively. However, the influence of working capital towards improvement in the performance of any organization cannot be overemphasized as indicated in the performance of the food and beverages industries in Nigeria by $1.37^{*} 10^{-9}$ due to the impact of working capital. Thus, the result shows that firms place 
more emphasis on working capital so as to enhance their profitability, viability and sustainability. The probability values of $0.000,0.000$ and 0.022 reveal that the estimated working capital management parameters; debt ratio, account receivable ratio and working capital from the model are statistically significant in assessing and determining the performance of food and beverages industries in Nigeria. The $41 \%$ adjusted $\mathrm{R}^{2}$ which depicts the proportion of variations or improvement in the performance of food and beverages industries in Nigeria captured by the level of return on assets can be explained by the working capital management. Thus, it signifies the important role which working capital management plays in enhancing industrial performance, growth and sustainability in Nigeria. Above all, the probability of the F- statistics 0.000 shows that the pooled generalized least square panel regression fitted is valid, reliable, appropriate and acceptable for determining the nexus of working capital management and performance of food and beverage industries in Nigerian context.

Table 2: Generalized Least Square Fixed Panel Regression Model Result

\begin{tabular}{lllll}
\hline Variables & Coefficients & S. Error & t-Statistics & Prob. Values \\
\hline C & 0.176305 & 0.012382 & 14.23885 & 0.0000 \\
ARR? & -0.120208 & 0.036440 & -3.298767 & 0.0018 \\
DER? & -0.122280 & 0.020376 & -6.001068 & 0.0000 \\
SGR? & $-1.13 \mathrm{E}-06$ & $2.52 \mathrm{E}-06$ & -0.449456 & 0.6550 \\
WCA? & $1.18 \mathrm{E}-09$ & $5.42 \mathrm{E}-10$ & 2.179323 & 0.0340 \\
Fixed Effects & & & & \\
(Cross-section) & & & & \\
_CNP_--C & -0.075364 & & & \\
-FMP_--C & -0.059565 & & & \\
-NNP_--C & 0.193945 & & & \\
-NBC_--C & -0.018709 & & & \\
_-7UP_-C & -0.040306 & & &
\end{tabular}

R-Squared $=0.67$ Adj. R-Squared $=0.62$ F-Stat. $=12.974$ Prob.(F-Stat. $)=0.000$

Source: Researcher's Computation 2016

In Table 2, the result of the fixed effect generalized least square panel regression model is presented and it is revealed that an inverse linear relationship exists among debt ratio, account receivable rate, sales growth and the return on assets which is the measure of performance in this paper but conversely, the result shows that only working capital has a positive linear relationship with return on assets. The result further indicates that the adopted components of variables depicting working capital management (account receivable rate, debt ratio and sales strategy) cause reduction in return on assets of the food and beverages industries in Nigeria by $12.0,12.2$ and $1.13^{*} 10^{-6}$ percent respectively. The improvement in the performance of food and beverages industries is as a result of the positive and undeniable working capital effect by increasing return on assets with $1.18^{*} 10^{-9}$ percent. The test for the statistical significance of these estimated parameters using the standard error test and the probability value reveal that working capital, account receivable and debt ratio of the food and beverages industries in Nigeria have contributed greatly to improve the level of return on assets and thereby, enhance the performance of the industries in Nigeria. A thorough examination of the result based on individual industry shows that working capital management or components under investigation improved the performance of the Nestle Nigeria plc by 19.4 percent. On the other hand, the performance of Cadbury Plc, Flour Mill Plc, Nigeria Bottling Company and 7up Plc are hampered as their performances are reduced by 7.54, 5.96, 1.87 and 4.03 percent respectively. This result affirms the opinion of Owolabi and Alu (2012) both of whom have worked on this subject matter in Nigeria for a period of 5 years and discover that each component of working capital significantly affects a firm's profitability at varying rates. Uremadu et al. (2012) also discover an inverse relationship between profitability and creditors' payment period. The proportion of variation and improvement in the performance of food and beverages industries in Nigeria which can be explained by the working capital management employed by these industries is $62 \%$. The probability of Fstatistics and the F-statistics value reveal that generalized least square fixed effect panel regression model is statistically significant and thus valid, reliable, appropriate and acceptable for this study. In comparing the pooled generalized least square panel regression model with the generalized least square fixed effect panel regression model used for this research based on evidence from the model with the highest value of $\mathrm{F}$ statistics, it is discovered that generalized least square panel regression model is more efficient, consistent, 
sufficient and unbiased for determining the impact of effective management of working capital on the performance of food and beverages industries in Nigeria taking cognizance of the firms' debt ratio.

\section{Conclusion and Suggestions for Further Research}

Having done a thorough evaluation of the impact of effective management of working capital on the performance of food and beverages industries in Nigeria, it is discovered from the analysis carried out using generalized least square panel regression model and all other diagnostics evaluation that working capital combination has much influence on the performance of food and beverages industries. The result shows a negative linear relationship between the following pairs of variable: return on asset and account receivable ratio; return on assets and debt ratio; return on assets and sales growth of the industry while a positive linear relation is discovered between return on assets and working capital of the industry. The result further reveals that the account receivable rate, debt ratio and sales growth reduce the industries' return on assets. However, the influence of working capital towards an improved performance of any organization cannot be overemphasized as the performance of the food and beverages industries in Nigeria increased due to the impact of working capital. Thus, the result shows the importance and the reasons why more emphasis must be placed on efficient management of working capital in order to enhance the profitability, viability, liquidity and sustainability of any industry. The probability values and the standard error values reveal that the estimated working capital management parameters such as account receivable ratio, debt ratio and working capital are statistically significant in assessing and determining the performance of food and beverages industries in Nigeria. Therefore, efficient working capital management tends towards strengthening strong cash flow, increases profitability, stabilizes budgeting and forecasting process and predicts risk visibility per time (Scherr, 1989).

The findings of this current paper agree with the above. The generalized least square panel fixed effect model shows that 62 percent variation or improvement in the performance of the food and beverages industries in Nigeria as witnessed in the level of return on assets can be explained by the working capital management. This definitely exhibits the important role which working capital management plays in enhancing industrial performance, growth and sustainability in Nigeria. Therefore, it can be recommended for managers of firms in Nigeria that they should formulate prudent working capital management policies and treat every decision on working capital as a risk return analysis so as to overcome liquidity crisis caused by high bad debt and maintain a balance between liquidity and firm profitability. Current assets and current liabilities should be kept by firms at an optimum level, that is, not to be in excess or in shortage form. Also, managers should restructure their accounts receivable days and debt ratio, improve on their sales strategy in order to enhance sales growth and also work towards keeping an efficient working capital level since all these have greater influence on firms' performance.

Suggestion for further Research: Would-be scholars can examine the nexus of dividend policy and working capital management as the availability of cash at times determine if the firm will choose dividend payout or dividend re-invest plans (DRIPs).

\section{References}

Akinlo, O. 0 (2012). Determinants of working capital requirements in selected quoted companies in Nigeria. Journal of African Business, 13(1), 40-50.

Aminu, Y. \& Zainudin, N. (2015). A Review of Anatomy of Working Capital Management Theories and the Relevant Linkages to Working Capital Components: A Theoretical Building Approach. European Journal of Business and Management, 7(2), 10-18.

Chand, S. (2016). Determinants of Working Capital of a Company. www.YourArticleLibrary.com

Deloof, M. (2003). Does working capital management affect profitability of Belgian firms? Journal of Business Finance \& Accounting, 30(3-4), 573-588.

Eljelly, A. M. (2004). Liquidity-profitability tradeoff: An Empirical Investigation in an Emerging Market. International Journal of Commerce and Management, 14(2), 48-61. 
Falope, O. I. \& Ajilore, O. T. (2009). Working Capital Management and Corporate Profitability: Evidence from Panel Data Analysis of Selected Quoted Companies in Nigeria. Research Journal of Business Management, 3(1), 73-84.

Ferreira, M. A. \& Vilela, A. S. (2004). Why do firms hold cash? Evidence from EMU countries. European Financial Management, 10(2), 295-319.

Filbeck, G., \& Krueger, T. M. (2005). An analysis of working capital management results across industries. American Journal of Business, 20(2), 11-20.

Ganesan, V. (2007). An analysis of working capital management efficiency in telecommunication equipment industry. Rivier Academic Journal, 3(1), 1-10.

Imeokparia, 0. (2015). Working Capital Management and Performance of Food and Beverage Industry in Nigeria. Research Journal of Finance and Accounting, 6(4), 196-202.

Kaur, J. (2010). Working Capital Management in Indian Tyre Industry, International Research Journal of Finance \& Economic, 46(1), 7-15.

Lyroudi, K. \& Lazaridis, Y. (2000). The Cash Conversion Cycle and Liquidity Analysis of the Food Industry in Greece (Electronic Version). EFMA 2000 Athens, from http://ssrn.com/paper=236175

Mukherji, A., Desai, A. B. \& Wright, P. (2008). A contingent relationship between risk and return: Towards a behavioural model of decision making. Institute of Behavioural and Applied Management, 2(1).

Muneer, S. (2015). An interaction between financial practices and firm performance with moderating effect of agency cost in Pakistani corporate sector. PhD thesis, Universiti Teknologi Malaysia, Faculty of Management.

Owolabi, S. A. \& Alu, C. N. (2012). Effective working capital management and Profitability: A study of selected quoted manufacturing companies in Nigeria. Economic and Finance Review, 2(6), 55-67.

Raheman A. \& Nasr, M. (2007). Working capital management and profitability - case of Pakistani firms. International review of business research papers, 3(2), 279-300.

Ray, S. (2012). Evaluating the impact of working capital management components on corporate profitability: evidence from Indian manufacturing firms. International Journal of Economic Practices and Theories, $2(3), 127-136$.

Sanger, J. (2001). Working capital: A modern approach. Financial Executive, 69.

Sharma, A. K. \& Kumar, S. (2011). The effect or working capital management of firm's profitability: Empirical Evidence from India, Global business Review, 12(1), 159 - 173.

Uremadu, J. A., Egbide, B. \& Enyi, P. E. (2012). Working capital management, liquidity and corporate profitability among quoted firms in Nigeria: Evidence from the productive sector. International Journal of Academic Research in Accounting, Finance and Management Sciences, 2(1), 80-97.

Wang, Y. J. (2002). Liquidity management, operating performance, and corporate value: evidence from Japan and Taiwan. Journal of Multinational Financial Management, 12(2), 159-169.

Wanguu, K. C. (2015). The Effect of Working Capital Management on The Profitability of Commercial and Services Firms Listed at the Nairobi Securities Exchange (Doctoral Dissertation, School of Business, and University Of Nairobi).

Yeboah, B. \& Agyei, S. K. (2012). Working capital management and cash holdings of banks in Ghana. European Journal of Business and management, 4(13), 120-130. 